\title{
FOOD-PACKAGING INTERACTION ON THE STABILITY OF CANNED SWEETENED CUPUAÇU (Theobroma grandiflorum Schum.) PUREE ${ }^{1}$
}

\author{
MARIA TERESA DE ALVARENGA FREIRE ${ }^{2 *}$, RODRIGO RODRIGUES PETRUS ${ }^{2}$, JOZETI APARECIDA \\ BARBUTTI GATTI ${ }^{3}$, MARIA FERNANDA BARBOSA LEITE ${ }^{2}$, MARIANA TOMIE KUNITAKE ${ }^{2}$, CELIA MARINA \\ DE ALVARENGA FREIRE ${ }^{4}$
}

\begin{abstract}
Cupuaçu (Theobroma grandiflorum Schum.) is an exotic fruit with a promising economic potential, particularly due to its strong aroma and creamy texture. This study aimed to produce sweetened cupuaçu puree and evaluate the effects of packaging corrosion on its sensory properties and shelf-life in tinplated cans. After 240 days of storage, the commercially sterile product had average sensory analysis scores of $5.89 \pm 0.21,5.39 \pm 0.30,5.45 \pm 0.21$ and $5.49 \pm 0.25$, for appearance, aroma, flavor and overall appreciation, respectively. Sensory acceptance scores did not change during storage $(\mathrm{p}>0.05)$. Corrosion potential and low tin and iron levels in the product, which are parameters used to evaluate food-packaging interaction, demonstrated the product remained food-safe throughout its shelf-life. Tinplate is a promising packaging material for sweetened cupuaçu puree due to its mechanical and protective properties. Furthermore, tin plating is an economically viable food technology to extend the shelf-life of cupuaçu products and expand its domestic and international markets.
\end{abstract}

Keywords: Corrosion. Sensory analysis. Theobroma grandiflorum Schum. Tinplate food packaging.

\section{INTERAÇÃO EMBALAGEM-ALIMENTO SOBRE A ESTABILIDADE DE DOCE DE CUPUAÇU (Theobroma grandiflorum Schum.)}

RESUMO - Cupuaçu (Theobroma grandiflorum Schum.) é uma fruta exótica, com potencial econômico promissor, especialmente devido ao seu forte aroma e textura cremosa. O objetivo deste estudo foi produzir um doce de cupuaçu e avaliar os efeitos da corrosão da embalagem sobre as propriedades sensoriais e vida útil do produto acondicionado em latas de folha de flandres. Após 240 dias de armazenamento, o produto

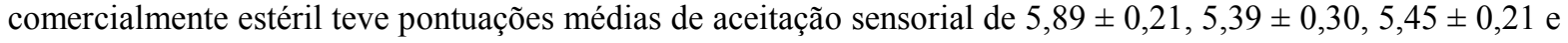
$5,49 \pm 0,25$, para a aparência, aroma, sabor e impressão global, respectivamente. As aceitações sensoriais não apresentaram alterações durante o armazenamento $(p>0,05)$. Medidas de potencial de corrosão e os baixos níveis de estanho e ferro no produto, que são parâmetros utilizados para avaliar a interação entre embalagem e alimento, demonstraram a segurança do produto ao longo da vida de prateleira. Os resultados obtidos mostraram que a folha de flandres é um material de embalagem promissor para o doce de cupuaçu devido às suas propriedades mecânicas e de proteção. O estudo demonstrou ainda que o processamento e acondcionamento em latas estanhadas é uma tecnologia economicamente viável para estender a vida de prateleira de produtos de cupuaçu e expandir seus mercados nacional e internacional.

Palavras-chave: Corrosão. Análise sensorial. Theobroma grandiflorum Schum. Embalagem de alimentos de folha de flandres.

\footnotetext{
*Corresponding author

${ }^{1}$ Received for publication in $04 / 24 / 2015$; accepted in 06/27/2016.

Paper extracted from research project at Department of Food Engineering, Faculty of Animal Science and Food Engineering, Universidade de São Paulo, in collaboration with Food Packaging Centre, Instituto de Tecnologia de Alimentos and Department of Materials Engineering, Faculty of Mechanical Engineering, Universidade de Campinas.

${ }^{2}$ Department of Food Engineering, Universidade de São Paulo, Pirassununga, SP, Brazil; freiremt@usp.br, rpetrus@usp.br, fefe_carter@hotmail.com, mtomiek@gmail.com.

${ }^{3}$ Food Packaging Centre, Instituto de Tecnologia de Alimentos, Campinas, SP, Brazil; jozeti@ital.sp.org.br.

${ }^{4}$ Department of Materials Engineering, Universidade de Campinas, SP, Brazil; celia@fem.unicamp.br.
} 


\section{INTRODUCTION}

Globally, Brazil is the third largest fruit producer and fifteenth ranked exporter in the agroindustry. However, according to Oliveira et al. (2012), Brazilian plant produce is not optimally exploited.

Cupuaçu (Theobroma grandiflorum Schum.) is an Amazonian fruit native to the region's rain forests (SANTOS et al., 2002). In addition to its domestic market potential, this fruit has been considered for international export, particularly to Europe (BASTOS et al., 2002; COSTA et al., 2003; SANTOS et al., 2010). Pará state is Brazil's main cupuaçu producer (approximately 41,142 tons in 2010 ). However, only $15 \%$ of cupuaçu production is exported, while $15 \%$ meets the local demand and $70 \%$ is sold in other Brazilian states. Its annual exports are growing, with a $241 \%$ increase from 2000 to 2010 (SAGRI, 2012).

Cupuaçu has a yellow-white acidic pulp and its sugar content is low. Its strong aroma and creamy texture make it highly suitable in juice, yogurt, ice-cream, jam, chocolate fillings and other processed products (BUENO et al., 2002, QUIJANO; PINO, 2007). Despite the growing demand for cupuaçu, post-harvest losses can vary from $15-50 \%$ due to the deficient quality control of the food chain.

One of the main difficulties in commercializing fresh cupuaçu pulp is that it deteriorates rapidly, particularly at points of sale located far from local production sites. To overcome this problem, pulp pasteurization and freezing have become widespread practices in Brazil, enabling high product volumes during the harvest period to provide year-round availability (BUENO et al., 2002; MASTELLA; MILAN, 2009). However, Clerici and Carvalho-Silva (2011), consider that there are many challenges to be solved in the regions where minor fruits are grown in Brazil, including the lack of scientific knowledge. The authors mention that basic processing operations by farmers results in products of low technological and microbiological quality. The authors emphasize the importance of generating technologies adapted to the current social and economic conditions and developing agricultural programs to reach the production sector.

Pasteurization of fruit pulp typically requires a high-temperature, short-time process to decrease the microbial flora and inactivate enzymes (TOCCHINI; NISIDA; DE MARTIN, 1995; VARIESMANN, 2008). Notwithstanding the advantages of the cold chain in the preservation of frozen fruit pulp, its costs are considerable. Therefore, alternative competitive technologies should be considered to increase the availability of this fruit on the market.

Food canning is employed worldwide for a variety of products. The structure of tinplate consists of a steel sheet with a tin coating applied by electrolytic deposition, covered with a chromium compound film. Internal protective lacquers are usually applied to prevent or minimize food-packaging interactions. In tinplate cans, acid food can contribute to the corrosion process. Corrosion causes metals, such as tin and iron, to dissolve, contaminating and in some cases altering, the sensory properties of the canned product (CATALÁ et al., 2005).

Considering the importance of cupuaçu in the Brazilian and international markets and the technologies available to expand the marketability of this tropical fruit, this work aimed to evaluate the food-packaging interaction of canned, sweetened, cupuaçu puree.

\section{MATERIALS AND METHODS}

The ingredients for this study were kindly donated by the following companies: frozen cupuaçu pulp (Theobroma grandiflorum Schum.) by De Marchi Ind. e Com. de Frutas Ltda (Jundiaí, SP, Brazil), and ethoxylated pectin $\left(150^{\circ} \mathrm{SAG}\right)$ by $\mathrm{CP}$ Kelco (Limeira, SP, Brazil). Sucrose was purchased locally. Food-grade potassium sorbate was purchased from Chemco Ind. e Com. Ltda (Hortolândia, SP, Brazil).

Sweetened cupuaçu puree was processed in a pilot plant at the Faculty of Animal Science and Food Engineering, University of São Paulo, Brazil. The puree comprised pulp/sucrose (1:1), $0.4 \%$ (pulp and sucrose total mass) pectin and $0.1 \%$ (pulp and sucrose total mass) potassium sorbate. The Figure 1 flowchart shows the processing of sweetened cupuaçu puree.

Pulp and sweetened puree were analyzed for moisture content, total ash, total titratable acidity, total soluble solids (TSS) and $\mathrm{pH}$, according to official Brazilian methods of analysis (BRASIL, 2005). All analyzes were performed in triplicate.

The moisture content was determined by drying $\sim 5 \mathrm{~g}$ in a forced draft oven at $100^{\circ} \mathrm{C}$ to constant weight.

Total ash was determined in a muffle furnace at $525^{\circ} \mathrm{C}$ using $\sim 5 \mathrm{~g}$ of sample placed in pre-calcined porcelain crucibles.

Total titratable acidity was determined on diluted samples by titration with $0.1 \mathrm{M} \mathrm{NaOH}$. Results were expressed as percentage citric acid.

The $\mathrm{pH}$ was measured with an MB-30 $\mathrm{pH}$ meter (Marte Balanças e Aparelhos de Precisão, Piracicaba, SP, Brazil), calibrated at $\mathrm{pH} 4$ and 7.

TSS was determined using a Reichert AR200 digital hand-held refractometer (Reichert Technologies, New York, USA), with automatic temperature compensation. 


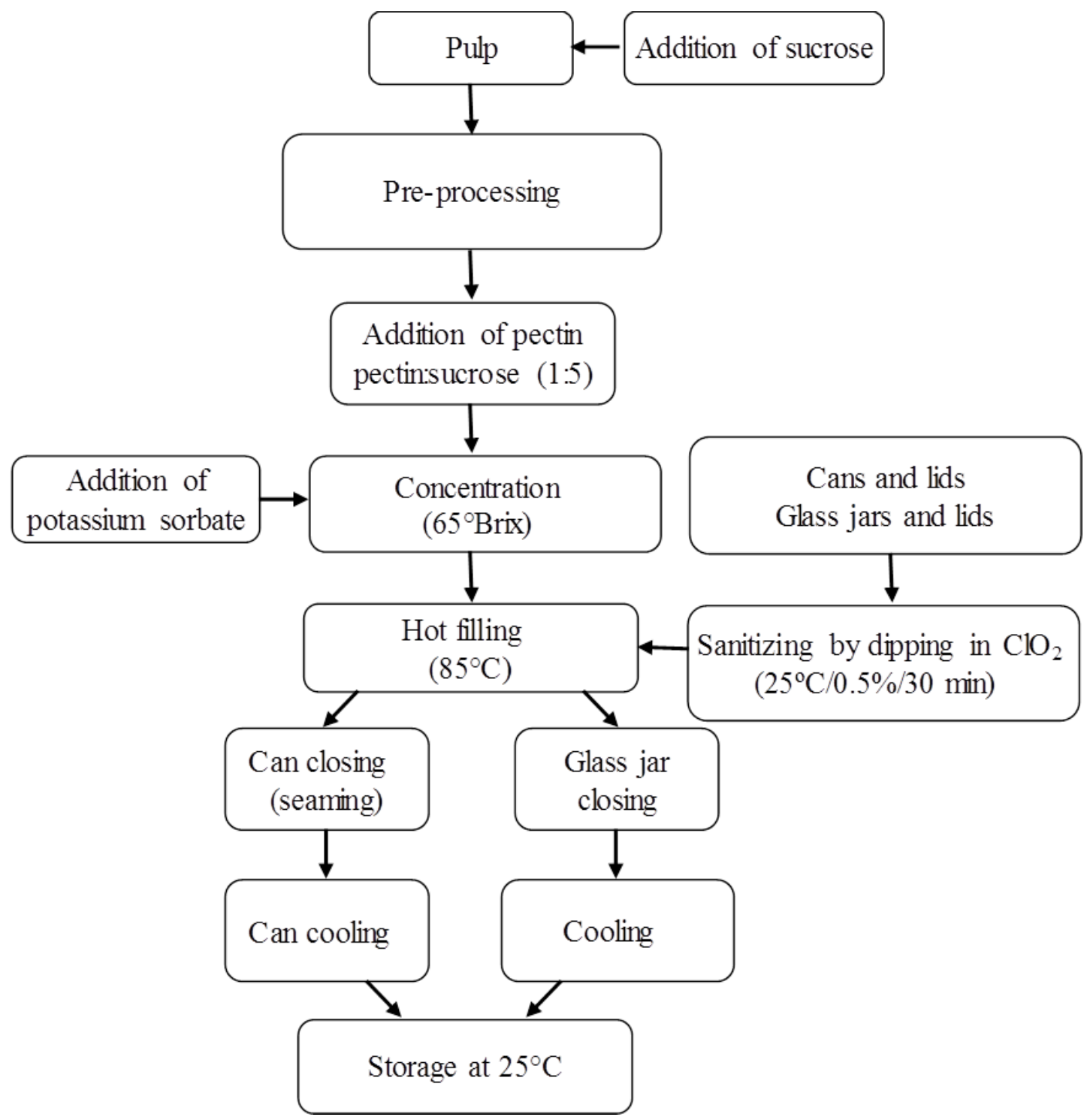

Figure 1. Processing flowchart of sweetened cupuaçu puree.

Water activity was measured by an AquaLab CX-2T hygrometer (Decagon Devices Inc., Pullman, WA, USA), precalibrated with saturated salt solutions.

Microbiological quality was determined by enumeration of the aerobic mesophilic bacteria, molds and yeasts, coliforms at 30 and $45^{\circ} \mathrm{C}$ and Salmonella spp. at 3-month intervals over 240 days. The analyzes were performed as described by Silva et al. (2010), except Salmonella detection, which was analyzed by the immunoprecipitation technique using a Salmonella VIP test kit (Biocontrol, USA), according to the AOAC Official Method 999.09 VIP.

The commercial sterility test involved incubation of the freshly processed batch at $25^{\circ} \mathrm{C}$ for 10 days in the dark, according to the method established by the American Public Health Association (APHA) for acidic foods $(\mathrm{pH}<4.6)$, described by Silva et al. (2010). After, five random samples were analyzed. Cans were opened, sensorially inspected and $\mathrm{pH}$ measured. A maximum variation of $\pm 0.2 \mathrm{pH}$ units was adopted to ensure the stability of the product. Samples that did not show signs of deterioration were microbiologically tested, using anaerobic thermoacidurans broth for Chlostridium butyricum spp and Bacillus coagulans, malt extract broth for molds and yeasts and all purpose tween for lactic bacteria. Samples that demonstrated butyric odor, broth turbidity and gas production were further tested by duplicate platings on thermoacidurans agar under aerobic and anaerobic conditions (using a pot with an anaerobic atmosphere generator), acidified potato dextrose agar and all purpose agar tween. Any changes observed in the color, odor, flavor and physical aspects were also recorded.

Tinplate three-piece cans $(400 \mathrm{~mL})$ were donated by Metalúrgica Mococa S.A. (Mococa, SP, Brazil). Type E 2.0/2.0 cans, referred to herein as TCI cans, contained a 2 g. $\mathrm{m}^{-2}$ layer of tin on both the inner and outer faces, two layers of epoxy phenolic lacquer on the inner face and one layer of epoxy 
phenolic lacquer on the outer face. Type D 5.6/2.8 g. $\mathrm{m}^{-2}$ cans, referred to herein as TCII cans, contained a 5.6 g.m $\mathrm{m}^{-2}$ outer and a $2.8 \mathrm{~g} . \mathrm{m}^{-2}$ inner layer of tin, and one layer of epoxy phenolic lacquer on both the inner and outer faces. The base and lid of both cans were made of tin-free steel. Glass jars $(400 \mathrm{~mL})$ were used as control packaging, and metal caps (Figure 1) were purchased from Labcenter (Campinas, SP, Brazil).

The inner tin coating of the can bodies was analyzed by a coulometric method, using an EG\&G 273 potentiostat/galvanostat system controlled by EG\&G software, as recommended by the Brazilian NBR8481 standard (ABNT, 2008). Each analysis was replicated five times.

The lacquer on the internal face of the body, base and lid of both cans was identified using a Perkin Elmer Spectrum 100 spectrophotometer, with direct readings on the cathodically detached film of the metallic substrate, using a $2 \%(\mathrm{~m} / \mathrm{v})$ sodium carbonate solution (DANTAS et al., 1996). All analyzes were performed in duplicate.

Lacquer adhesion tests were performed according to the ASTM 3359-02 standard, by making 12 scratches in a grid pattern $\left(\begin{array}{lll}6 & \mathrm{x} & 6\end{array}\right)$ perpendicular to each other, with $1 \mathrm{~mm}$ spacing (ASTM, 2008). 3M Scotch premium-grade transparent cellophane tape, code $610-1 \mathrm{PK}, 25.4 \mathrm{~mm}$ wide was used. The degree of adhesion was based on a scale ranging from $0 \mathrm{~B}$ (detachment $>65 \%$ ) to $5 \mathrm{~B}$ (zero detachment). The lacquer was also detached with a $\mathrm{CuSO}_{4}$ acid solution applied to the metallic surface (DANTAS et al., 1996). Five analyzes were performed on the body, base and lid of both cans.

The porosity of the inner lacquer (body, base, lid) was determined electrochemically (10 replicates), using a WACO Enamel Rater II instrument, applying $6.2 \mathrm{~V}$ after filling the cans with a $2 \% \mathrm{Na}_{2} \mathrm{SO}_{4}$ solution (DANTAS et al., 1996). The amount of electrical current generated is proportional to the area of exposed metal. The lids were evaluated using a specific device. Porosity was expressed as $\mathrm{mA} /$ can or $\mathrm{mA} / \mathrm{lid}$.

The lacquer cure grade of the body, base and lid of both cans ( 5 samples per can) was evaluated by the absorption method, applying a methyl violet solution on the lacquered surface. Curing was assessed based on the intensity of color absorption (DANTAS et al., 1996).

The internal pressure (vacuum) was determined using a Willy vacuum gauge with a capacity of $30 \mathrm{Hg}$ and $0.5 \mathrm{Hg}$ resolution (DANTAS et al., 1996).

Metal analysis of iron, tin and chrome migration from the cans to the puree was determined by inductively coupled plasma optical emission spectrometry (ICP-OES), using a Perkin Elmer 3000 DV spectrometer. The calibration curve was prepared using standard solutions $\left(1000 \mu \mathrm{g} . \mathrm{mL}^{-1}\right)$ of chrome, iron and tin (AccuTrace 3112a, 3126a and
3161, respectively, NIST, USA). Quantification was based on external calibration curves. Samples $(1.0 \pm$ $0.1 \mathrm{~g})$ containing $5 \mathrm{~mL}$ of $\mathrm{HNO}_{3}$ and $5 \mathrm{~mL}$ of deionized water were heated (hot plate) to decrease the volume. Then, $5 \mathrm{~mL}$ of $\mathrm{HCl}$ and $5 \mathrm{~mL}$ of deionized water were added. After, two repeats of $\mathrm{HNO}_{3}(5 \mathrm{~mL})$, followed by $\mathrm{HCl}(5 \mathrm{~mL})$ were added. The final volume was adjusted to $50 \mathrm{~mL}$. Analyzes were performed in duplicate.

The sensory acceptance of the sweetened cupuaçu puree was assessed by a sensory panel consisting of 50 untrained panelists. The panelists were asked to evaluate the puree for appearance, aroma, flavor, and overall appreciation of the product by assigning a score on a 7-point structured hedonic scale $(1=$ dislike very much; $4=$ neither like nor dislike; $7=$ like very much). The tests were carried out in individual booths under a white light, and the samples (TCI, TCII and control) were presented monadically in $50 \mathrm{~mL}$ plastic cups labeled with a 3-digit code, at $\sim 15^{\circ} \mathrm{C}$. Samples packaged in glass jars served as the control. The samples were presented in a completely randomized block design. Mineral water was provided to cleanse the palate. Tests were performed at 60-day intervals. Considering the exotic flavor of the product and that most of the panelists had never tasted the fruit before, average scores greater than four were used as threshold values for all the attributes assessed (MEILGAARD; CIVILLE; CARR, 1999, STONE; SIDEL, 1993).

In addition, a difference-from-control test was carried out to determine whether there was any difference between samples stored in glass jars (control) and in tinplate cans (as proposed packaging) during the storage time, and to estimate the magnitude of any such difference. A panel of 50 individuals was asked to rate the magnitude of the difference between the sample and the control by assigning a score on a 5-point structured scale $(0=$ no difference between sample and control; $2=$ moderate difference; $4=$ very large difference) (MEILGAARD; CIVILLE; CARR, 1999, STONE; SIDEL, 1993). All the samples were served to the sensory panel under the same abovementioned conditions as those used in the test with the hedonic scale.

The sensory assessment data were statistically analyzed by analysis of variance, using Tukey's test with significance at 5\%. The difference-from-control test data were analyzed by Dunnett's $t$-test, using the statistical software program SAS 9.1.

\section{RESULTS AND DISCUSSION}

An important aspect of this study was to analyze the physical and chemical characteristics of sweetened cupuaçu puree. A previous study demonstrated that the heterogeneity of cupuaçu pulp 
from various suppliers affects the product quality parameters, particularly its $\mathrm{pH}$, total titratable acidity and TSS (FREIRE et al., 2009). These differences are ascribed to the intrinsic characteristics of the fruit composition. In addition, it is common for raw frozen fruit pulp to be transported to other regions of the country for processing and sale.

Table 1 lists the quality parameters for pulp and sweetened puree. The pulp did not meet the minimum quality standards for $\mathrm{pH}$ (BRASIL, 2000). In particular, the low $\mathrm{pH}$ of the product is one of the main parameters of interest in food-packaging interaction studies.
The tinplate can characteristics are shown in Tables 2 and 3. Table 2 describes the total tin layer determined in the inner face of the body. Table 3 reports the dry layer, adhesion, porosity and curing degree of the inner lacquer layer applied to the body, lid and base of the TCI and TCII cans. The lacquer layer on the TCI body was on average $20 \%$ thicker than that of the TCII cans. However, the base and lid of the TCI and TCII cans were not significantly different $(p>0.05)$. The lacquer on the TCII body showed an average detachment of $5-15 \%$ in the sampled area, while the TCI tinplate body showed no detachment of the lacquer.

Table 1. Physical and chemical characterization of cupuaçu pulp and sweetened puree.

\begin{tabular}{|c|c|c|c|}
\hline Parameter & Pulp & Pulp $^{(3)}$ & Sweetened puree \\
\hline Dry matter $\left({\left.\mathrm{g} 100 \mathrm{~g}^{-1}\right)}^{-1}\right.$ & $9.3 \pm 0.6$ & & $68 \pm 5$ \\
\hline Water activity & $0.9913 \pm 0.0006$ & 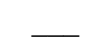 & $0.84 \pm 0.02$ \\
\hline 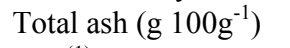 & $0.69 \pm 0.05$ & & $0.33 \pm 0.02$ \\
\hline $\operatorname{TSS}^{(1)}\left({ }^{\circ}\right.$ Brix $)$ & $8.8 \pm 0.7$ & $\overline{9.0}$ & $60 \pm 1$ \\
\hline $\mathrm{TTA}^{(2)}$ & $1.5 \pm 0.1$ & 1.50 & $0.80 \pm 0.05$ \\
\hline $\mathrm{pH}$ & $3.54 \pm 0.05$ & 2.60 & $3.75 \pm 0.02$ \\
\hline
\end{tabular}

Means of three replicates \pm standard deviation (total of nine evaluations of pulp and sweetened puree).

(1) Total soluble solids. (2) Total titratable acidity expressed as percentage citric acid $\left(\mathrm{g} 100 \mathrm{~g}^{-1}\right)$. (3) Minimum quality levels according to normative instruction no. 1, 07 Jan 2000 (BRASIL, 2000).

Table 2. Inner tin coating on the body of TCI and TCII cans.

\begin{tabular}{cccc}
\hline \multirow{2}{*}{ Tin coating } & g.m ${ }^{-2(1)}$ & $\begin{array}{c}\text { Variation } \\
\text { interval }\end{array}$ \\
\hline \multirow{3}{*}{ TCI } & Free & $1.30 \pm 0.07$ & $1.20-1.36$ \\
& Alloy & $0.71 \pm 0.04$ & $0.65-0.75$ \\
& Total & $2.01 \pm 0.08$ & $\mathbf{1 . 8 9}-\mathbf{2 . 1 1}$ \\
\cline { 2 - 4 } TCII & Free & $1.75 \pm 0.22$ & $1.40-1.94$ \\
& Alloy & $0.97 \pm 0.06$ & $0.89-2.28$ \\
& Total & 2.720 .27 & $\mathbf{2 . 2 8}-\mathbf{2 . 9 6}$ \\
\hline
\end{tabular}

(1) Mean values of five replicates \pm standard deviation.

The lacquer of the TCI body and lid showed a higher average porosity than the TCII cans. Note that the literature lacks a porosity reference value for three-piece cans. Regarding the TCI samples, $80 \%$ showed exposed metal, particularly in the double seam region. The TCII cans also had exposed metal, mainly in the welded region and the double seam area showed bubble formation in $30 \%$ of the samples. Both TCI and TCII cans showed the bubble formation in the body and base. However, both cans had a properly cured inner coating; the methyl violet dye was only slightly absorbed by the lacquered surface.

Published sensory data on cupuaçu products are limited. Vieira and Silva (2004) evaluated cupuaçu juice with emphasis on a descriptive analysis aimed at optimizing the formulations. Scientific data on the stability of cupuaçu products in tinplate packaging are not available in the literature.

In general, the average of all the acceptance scores varied from 5 to 6 , corresponding to "like slightly" and "like moderately." Due to the lack of a similar product on the market, the panelists likened the product to jelly, which led them to expect the sweetened puree to be more viscous and firmer. Since cupuaçu is an exotic fruit and is not as widespread compared to other tropical fruits, it was concluded that the score obtained for the sweetened puree represented a good level of acceptance for its aroma and flavor. 
M. T. A. F. FREIRE et al.

Table 3. Characteristics of the TCI and TCII cans used to package sweetened cupuaçu puree.

\begin{tabular}{|c|c|c|c|c|c|c|c|}
\hline \multirow[t]{3}{*}{ Parameters } & & \multicolumn{6}{|c|}{ Results } \\
\hline & & \multicolumn{2}{|c|}{ Body } & \multicolumn{2}{|c|}{ Base } & \multicolumn{2}{|c|}{ Lid } \\
\hline & & TCI & TCII & TCI & TCII & TCI & TCII \\
\hline \multirow{4}{*}{ Dry layer $\left(\mathrm{g} \mathrm{m}^{-2}\right)^{(1)}$} & $\mathrm{A}$ & 9.36 & 7.83 & $6.07^{\mathrm{a}}$ & $6.52^{\mathrm{a}}$ & $7.43^{\mathrm{b}}$ & $7.23^{b}$ \\
\hline & SD & 0.31 & 0.37 & 0.66 & 0.67 & 0.14 & 0.32 \\
\hline & Min. & 9.14 & 7.42 & 5.29 & 5.39 & 7.30 & 6.92 \\
\hline & Max. & 9.90 & 8.24 & 6.99 & 7.08 & 7.64 & 7.72 \\
\hline \multirow[t]{3}{*}{ Level of adhesion $^{(1,2)}$} & $\mathrm{A}$ & $5 \mathrm{~B}$ & $3 \mathrm{~B}$ & $5 \mathrm{~B}$ & $5 \mathrm{~B}$ & $5 B$ & $5 \mathrm{~B}$ \\
\hline & Min. & $4 \mathrm{~B}$ & $2 \mathrm{~B}$ & $5 \mathrm{~B}$ & $5 \mathrm{~B}$ & $5 \mathrm{~B}$ & $5 \mathrm{~B}$ \\
\hline & Max. & $5 \mathrm{~B}$ & $4 \mathrm{~B}$ & $5 \mathrm{~B}$ & $5 \mathrm{~B}$ & $5 \mathrm{~B}$ & $5 \mathrm{~B}$ \\
\hline & & \multicolumn{4}{|c|}{ Body/base } & \multicolumn{2}{|c|}{ Lid } \\
\hline \multirow[t]{5}{*}{ Porosity $(\mathrm{mA})^{(3,4)}$} & & \multicolumn{2}{|c|}{ TCI } & \multicolumn{2}{|c|}{ TCII } & TCI & TCII \\
\hline & A & \multicolumn{2}{|c|}{94.6} & \multicolumn{2}{|c|}{75.7} & 0.7 & 0.0 \\
\hline & SD & \multicolumn{2}{|c|}{27.0} & \multicolumn{2}{|c|}{17.3} & 1.0 & 0.0 \\
\hline & Min. & \multicolumn{2}{|c|}{61.2} & \multicolumn{2}{|c|}{41.4} & 0.0 & 0.0 \\
\hline & Max. & \multicolumn{2}{|c|}{135.3} & \multicolumn{2}{|c|}{95.3} & 2.8 & 0.0 \\
\hline Curing & & \multicolumn{2}{|c|}{$\begin{array}{l}\text { Low intensity stain in } \\
\text { TCI and TCII samples }\end{array}$} & \multicolumn{2}{|c|}{$\begin{array}{l}\text { Low intensity stain in } \\
\text { TCI and TCII samples }\end{array}$} & \multicolumn{2}{|c|}{$\begin{array}{l}\text { Low intensity stain in } \\
\text { TCI and TCII samples }\end{array}$} \\
\hline
\end{tabular}

$\mathrm{A} / \mathrm{SD} / \mathrm{Min} / \mathrm{Max}=$ Average/Standard deviation/Minimum value/Maximum value. Results for dry layer measured in bases and lids on the same line, averages followed by the same letter do not differ at $5 \%$ significance.

(1) Five replicates. (2) Percentage of detachment: $5 \mathrm{~B}=0 \%, 4 \mathrm{~B}=<5 \%, 3 \mathrm{~B}=5-15 \%, 2 \mathrm{~B}=15-35 \%, 1 \mathrm{~B}=35-65 \%, 0 \mathrm{~B}$

$=>65 \%$. (3) 10 replicates. (4) Results expressed as $\mathrm{mA} /$ tin can for analysis of body/base and $\mathrm{mA} /$ lid for lids.

The results indicated that the structure of the TCI and TCII tin cans did not affect the sensory acceptances of sweetened cupuaçu puree, despite the migration of tin and iron. The samples showed no significant difference during storage for appearance, aroma, flavor and overall appreciation $(\mathrm{p}>0.05)$. According to the sensory criteria established in this research (average scores above 4 for all sensory attributes), the product quality remains unchanged for a minimum 240 days of storage. Indeed, the sensory acceptance scores remained unchanged during the 240 days, as indicated by the low variation in the average score, except for the aroma score, which tended slightly upward (Figure 2). Moreover, based on the control test in which the sweetened puree was packaged in traditional glass jars, the tinplate packaging did not affect the sensory properties of the product i.e., no statistical difference was found $(\mathrm{p}>0.05)$.

The physical and chemical properties of food can influence the performance of packaging during storage, especially over a long shelf-life. The safety of a packaging material is associated with its interaction with the food in contact with it. Migration processes cause the packaged food to become contaminated, in some instances with substances of toxicological concern. In addition, the transfer of components from the packaging to the food product may alter the sensory properties of the food, decreasing its consumer acceptance. For tinplate cans, acid foods can contribute to the corrosion process, with the possible migration of metal components, particularly iron, tin and chrome (CrIII). Maximum levels of inorganic contaminants in food are established by the Brazilian National Health Surveillance Agency (ANVISA) ordinance no. 685 (BRASIL, 1998) and technical regulation no. 42 (BRASIL, 2013). According to these regulations, the maximum allowable concentration of tin in canned foods, other than beverages, is $250 \mathrm{mg} \cdot \mathrm{kg}^{-1}$. Brazilian standards do not establish limits for chrome and iron. Moreover, there is no reference for inorganic contaminant limits related to the product evaluated in this research. Therefore, the limit for canned foods was considered the safety level for sweetened cupuaçu puree.

Iron and tin were identified and quantified in the sweetened cupuaçu puree as the main contaminants and indicators of the corrosion process in tin cans and in the lids of the glass jars. Chrome was not detected in the food samples at any time during the storage period. Tin was detected in the food product packaged in glass jars, with levels varying from 3-4 mg. $\mathrm{kg}^{-1}$. Tin levels varied from 7-9 and 3-4 mg. $\mathrm{kg}^{-1}$ in the TCI and TCII cans, respectively. The tin levels in the replicates of the same packaging over the same storage period were not uniform, suggesting the heterogeneous nature of the tinplate can samples, probably due to the non-uniform inner layer of lacquer applied to the metallic surfaces. Iron migration into the cupuaçu product showed a similar trend. Iron levels in the TCI and TCII cans varied, respectively, from 10-37 mg. $\mathrm{kg}^{-1}$ and from less than 15 up to $35 \mathrm{mg} \cdot \mathrm{kg}^{-1}$. Migration of tin and iron started on day 30 of storage and continued until the end of the 240 days, suggesting that the initial corrosion process occurred rapidly, although the low levels found in the product at the end of the storage time suggest that subsequent corrosion occurred at a slower rate. Considering the limits established by the Brazilian standards, the level of contamination was much lower than the maximum concentration allowed for canned foods, confirming the safety (taken as reference) of both the TCI and TCII tin cans. 

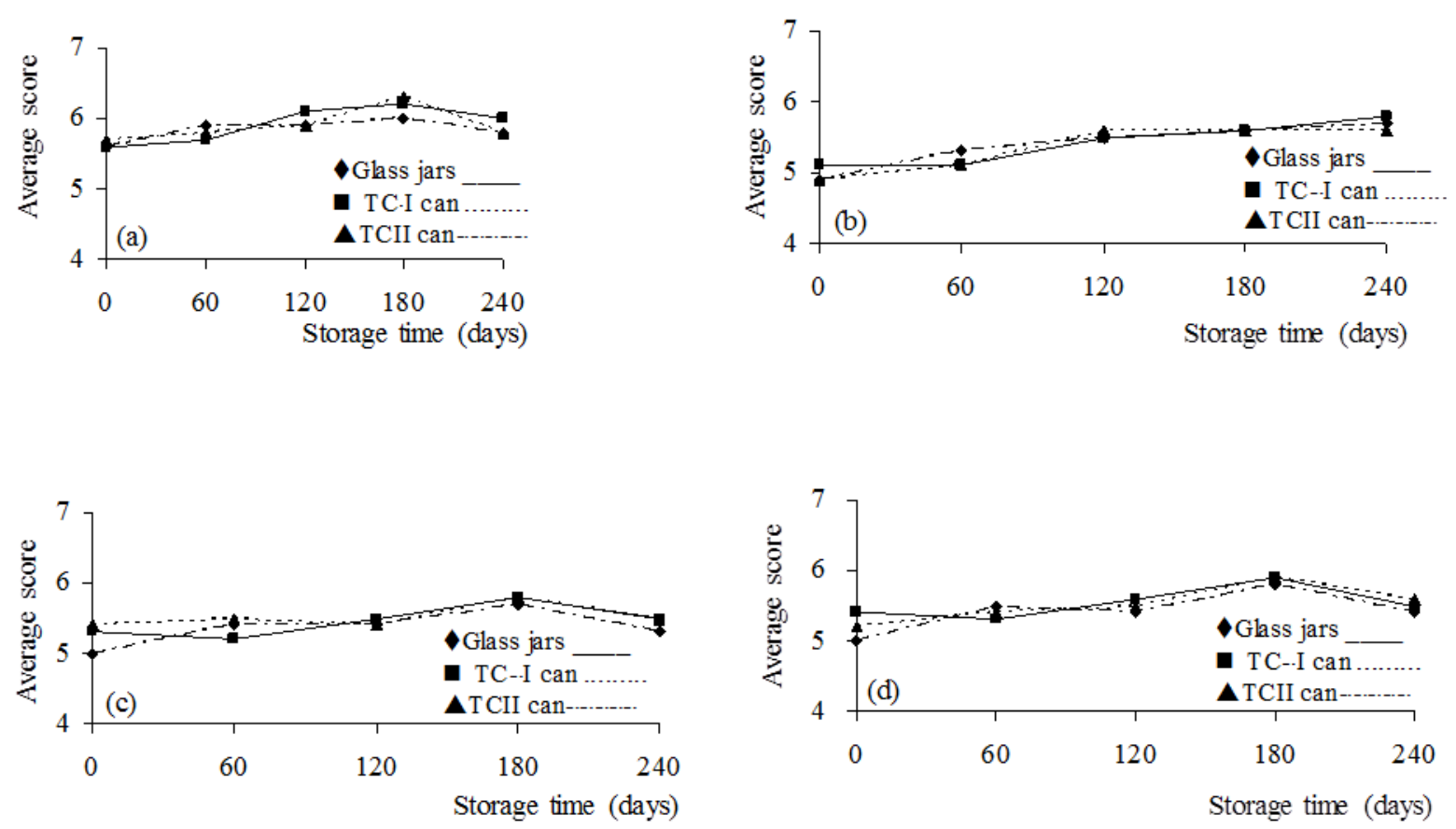

Figure 2. Acceptance evaluation of sweetened cupuaçu puree stored for 240 days. (glass jars, TCI can, TCII can). (a) Appearance, (b) Aroma, (c) Flavor, (d) Overall appreciation.

Interestingly, the product showed higher levels of iron than tin as the result of the food-packaging interaction. Corrosion is an electrochemical phenomenon, involving electron transfer or displacement. When two dissimilar metals are immersed in an electrolyte and then connected, a galvanic cell is formed. The electric potential established between the two metals enables the transfer of electrons. Regarding the food-packaging interaction, food acts as the electrolyte while tin and steel act as electrodes. In lacquered tinplate cans in contact with food, the galvanic cell results from porosity or a deficient coating. Thermodynamically, steel is more active than tin, so steel acts as the anode and tin as the cathode. However, tinplate packaging and food constitute a deaerated system and when in contact with acid foods, particularly vegetal products, the system may show an inversion in polarity, with tin acting as the "sacrificial" anode.

The corrosion potential was measured at 30 , 60 and 90 days of storage (Table 4) to evaluate the food-packaging interaction. In this evaluation, only the TCI can type was used because both types were made of the same alloy. Analyzes were carried out on the plain steel (after removal of the tin layer from the can) and on the tinplate, both in contact with sweetened cupuaçu puree. The corrosion potential of plain steel was considered the reference due to its direct exposure to the product and was determined only on initial exposure. It was found that on contact with sweetened cupuaçu puree, the tin showed cathodic behavior during the first 30 days of immersion. The results suggest an inversion in polarity between 30-60 days of storage, with tin behaving anodically in relation to iron. Another inversion occurred from 60-90 days of storage, with tin behaving as the cathode in relation to steel. The results do not clearly indicate why the levels of iron in the product were higher than those of tin. However, these results suggest a polarity inversion in the galvanic cell between tin and iron in tin cans in contact with the cupuaçu product.

Limited information is available that can explain this "zigzag" change in polarity. Some hypotheses proposed emphasize the protective action of lacquer on the can surface, the absence of tin chelating agents, or the presence of stable iron chelating agents (BERNARDO et al., 2002; FELIPE et al., 2008). Pelici (2012) evaluated the corrosion behavior of tin cans in direct contact with several acid organic solutions, including citric, malic and acetic acids. The author found that depending on the chelating anions, iron and steel can assume different relative positions in relation to the corrosion potential, with changes in behavior as anode or cathode, thus, influencing the corrosion mechanism.

Considering these studies, the results obtained with canned sweetened cupuaçu puree suggest that the natural organic acids of this tropical fruit probably chelate the metallic ions $(\mathrm{Fe} / \mathrm{Sn})$, forming complexes that promote this oscillating behavior.

Vacuum measurements of both TCI and TCII cans throughout the storage period indicated that their hermeticity remained unchanged; hence, metal dissolution was not influenced by this variable. 
Table 4. Measure of corrosion potential of the TCI tin can.

\begin{tabular}{cccc}
\hline \multicolumn{4}{c}{ Corrosion Potential $\mathrm{mV}$ vs. SCE } \\
\hline Steel & 30 days & 60 days & 90 days \\
-0.65 & -0.52 & Tin & \\
& & -0.70 & -0.54 \\
\hline
\end{tabular}

(1) $\mathrm{SCE}=$ reference saturated calomel electrode.

Considering these studies, the results obtained with canned sweetened cupuaçu puree suggest that the natural organic acids of this tropical fruit probably chelate the metallic ions $(\mathrm{Fe} / \mathrm{Sn})$, forming complexes that promote this oscillating behavior.

Vacuum measurements of both TCI and TCII cans throughout the storage period indicated that their hermeticity remained unchanged; hence, metal dissolution was not influenced by this variable.

\section{CONCLUSIONS}

Tinplate is a highly promising packaging material for sweetened cupuaçu puree due to its mechanical and protective properties. The ability of the canned tin to maintain the product quality throughout its shelf-life i.e., minimum 240 days at ambient temperature, creates opportunities to expand the domestic and export markets of cupuaçu products.

The low levels of metal migration confirmed that both the tin can and glass jar packaging met food safety requirements. Considering the detachment of lacquer observed at 180 days of storage, it is recommended that manufacturers improve the quality of the lacquer coating, particularly the adhesion and minimization of pinholes. This study demonstrated that the interaction between the food product and metal packaging is a complex process and further studies are needed to gain a better understanding of the corrosion phenomenon.

The sensory scores were maintained between "like slightly" and" like moderately, indicating that the acceptance did not change during storage $(p>0.05)$. Considering the fact that cupuaçu and its products are being increasingly introduced into regions outside the Amazon, the production of sweetened cupuaçu puree is an interesting alternative for the sustainable exploitation of this fruit. The technology used in this study can contribute to income generation for agricultural properties where this fruit is grown.

\section{REFERENCES}

AMERICAN SOCIETY FOR TESTING AND MATERIALS. D 3359: Standard test method for measuring adhesion by tape test. Philadelphia, 2008, $4 \mathrm{p}$.
ASSOCIAÇÃO BRASILEIRA DE NORMAS TÉCNICAS. NBR 8481: Determinação do revestimento de estanho pelo método coulométrico (eletrolítico) - método de ensaio. Rio de Janeiro, 2008, 6 p.

BASTOS, M. S. R. et al. Efeitos da aplicação de enzimas pecnolíticas no rendimento da extração de polpa de cupuaçu. Revista Brasileira de Fruticultura, Cruz das Almas, v. 24, n. 1, p. 240-242, 2002.

BERNARDO, P. E. M.; CAMARGO, C. D. T.; COSTA, N. G. Avaliação do processo de corrosão em folhas-de-flandres com e sem revestimento orgânico interno, utilizadas para conservas de pêssego. In: COTEQ CONFERÊNCIA SOBRE TECNOLOGIA DE EQUIPAMENTOS, 6, COMBRASCORR CONGRESSO BRASILEIRO DE CORROSÃO, 22，2002， Salvador. Anais... Salvador, $12 \mathrm{p}$.

BRASIL. Agência Nacional de Vigilância Sanitária. ANVISA - Portaria No 685, 27 de agosto de 1998. Regulamento Técnico: "Princípios Gerais para o Estabelecimento de Níveis Máximos de Contaminantes Químicos em Alimentos" e seu Anexo: "Limites máximos de tolerância para contaminantes inorgânicos". Disponível em: http:// www.anvisa.gov.br. Acesso em: 05 abr. 2016.

BRASIL. Agência Nacional de Vigilância Sanitária. ANVISA - Resolução de Diretoria Colegiada RDC $N^{o}$ 42, 29 de agosto de 2013. Regulamento Técnico sobre Limites Máximos de Contaminantes Inorgânicos em Alimentos. Disponível em: http:// www.anvisa.gov.br. Acesso em: 15 maio 2016.

BRASIL. Ministério da Agricultura, Pecuária e do Abastecimento. Instrução Normativa $\mathrm{N}^{\circ} 1,07 \mathrm{de}$ janeiro de 2000. Regulamento técnico geral para fixação dos padrões de identidade e qualidade para polpa de fruta. Diário Oficial da República Federativa do Brasil, Brasília, DF, 10 de janeiro, Seção 1, p. 54.

BRASIL. Ministério da Saúde. Agência Nacional de Vigilância Sanitária. ANVISA - Instituto Adolfo Lutz. Métodos Físico-Químicos para Análise de Alimentos, (Série A. Normas e Manuais Técnicos). Brasília: Agência Nacional de Vigilância 
Sanitária, Brasília: Ministério da Saúde, 2005, 1017 p.

BUENO, S. M. et al. Avaliação da qualidade de polpas de frutas congeladas. Revista Instituto Adolfo Lutz, São Paulo, v. 61, n. 2, p. 121-126, 2002.

CATALÁ R. et al., Cristaforo N. Titanium-passivated tinplate for canning foods. Food Science and Technology International, London, v. 11, n. 3, p. 223-227, 2005.

CLERICI, M. T. P. S.; CARVALHO-SILVA, L. B. Nutritional bioactive compounds and technological aspects of minor fruits grown in Brazil. Food Research International, Barking, v. 44, n. 7, p. 1658-1670, 2011.

COSTA, M. C. et al. Conservação de polpa de cupuaçu (Theobroma grandiflorum (Willd. Ex Spreng.) Schum) por métodos combinados. Revista Brasileira de Fruticultura, Cruz das Almas, v. 25, n. 2, p. 213-215, 2003

DANTAS, S.T. et al. Avaliação da qualidade de embalagens metálicas: aço e alumínio. 1. ed. Campinas, SP: CETEA/ITAL, 1996. 317 p.

FELIPE, A. M. P. et al. Avaliação do desempenho do envernizamento interno de latas em folha-de-flandres por espectroscopia de impedância eletroquímica - resultados preliminares. In: CONGRESSO BRASILEIRO DE CORROSÃO, 28, INTERNATIONAL CORROSION MEETING (INTERCORR), 2, 2008, Recife. Anais... Recife, 2008. p. 282-294.

FREIRE, M. T. A. et al. Caracterização físico-química, microbiológica e sensorial de polpa de cupuaçu congelada (Theobroma grandiflorum Schum). Brazilian Journal of Food Technology, Campinas, v. 12, n. 1, p. 9-16, 2009.

MASTELLA, A. S.; MILAN, F. N. Estratégia de marketing no segmento de produtos hortifruticolas processados: Análise de uma empresa do setor. Revista de Ciências Gerenciais, Valinhos, v. 13, n. 17, p. 97-112, 2009.

MEILGAARD, M.; CIVILlE, G. V.; CARR, B. T. Sensory evaluation techniques. 3. ed., London, New York, Washington DC: CRC Press LLC, Boca Raton, 1999, 453 p.

OLIVEIRA, V. B. et al. Native foods from Brazilian biodiversity as a source of bioactive compounds. Food Research International, Barking, v. 48, n. 1, p. 170-179, 2012.
PELICI, B. O. Análise de simulantes para produtos ácidos acondicionados em embalagens metálicas. 2012. 115 f. Dissertação (Mestrado em Engenharia Mecânica: Área de Concentração em Materiais e Processos de Fabricação) - Universidade Estadual de Campinas, Campinas, 2012.

QUIJANO, C. E.; PINO, J. A. Volatile compounds of copoazú, (Theobroma grandiflorum Schum) fruit. Food Chemistry, London, v. 104, n. 3, p. 1123-1126, 2007.

SANTOS G. M. et al. Antioxidant activity and correlations with bioactive components from commercial products of cupuaçu. Ciência Rural, Santa Maria, v. 40, n. 7, p. 1636-1642, 2010.

SANTOS, S. C. M. et al. Diagnóstico Organizacional e Tecnológico da Agroindústria de Polpa de Fruta do município de São Luís-MA, com vista à implementação de um Programa de Controle de Qualidade. In: XIV Seminário de Iniciação Científica da UEMA e VII Encontro de Iniciação Científica da UEMA, Livro de Resumos, São Luís, 2002, p. $48-52$.

SECRETARIA DE ESTADO DE AGRICULTURA. SAGRI - A fruticultura no estado do Pará. 2012 Disponível em: http://www.sagri.pa.gov.br/ publicacoes/ view/77/ a_fruticultura_no_estado_do_para. .Acesso em 15 ābr. 2016.

SILVA, N. et al. Manual de métodos de análise microbiológica de alimentos. 3. ed. Santa Maria, RS: Varela, 2010. 536 p.

STONE, H.; SIDEL, J. L. Sensory evaluation practices. 2nd ed., San Diego: Academic Press, 1993, 438 p.

TOCCHINI, R. P.; NISIDA, A. L. A. C.; DE MARTIN Z. J. Industrialização de polpas, sucos e néctares de frutas. Manual Técnico. Campinas: Fruthotec ITAL, 1995, 85 p.

VARIESMANN, L. C. Extração, caracterização e aspectos reológicos de polissacarídeos da polpa dos frutos de Theobroma grandiflorum (cupuaçu). 2008. 117 f. Dissertação (Mestrado em Ciência Bioquímica: Área de Concentração em Bioquímica) - Universidade Federal do Paraná, Curitiba.

VIEIRA, M. C.; SILVA, C. L. M. Optimization of a cupuaçu (Theobroma grandiflorum) néctar formulation. Journal of Food Process Engineering, Westport, v. 27, n. 3, p. 181-196, 2004. 